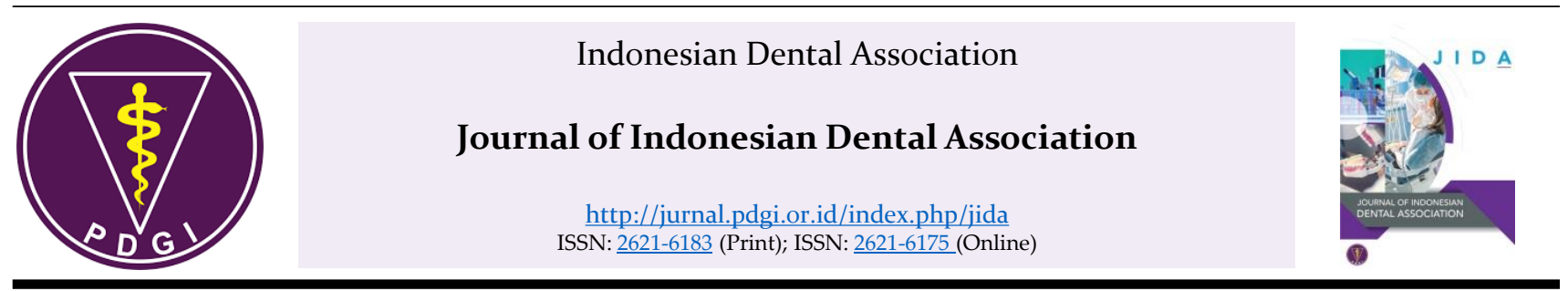

Research Article

\title{
The Effect Ant-Nest Plant \\ (Myrmecodia pendans) Extract on Streptococcus sanguinis and Treponema denticola Biofilms
}

\author{
Nely Soviati ${ }^{1}$, Armelia Sari Widyarman ${ }^{2 \S}$, Ciptadhi Tri Oka Binatha ${ }^{2}$ \\ ${ }^{1}$ Undergraduate Student, Faculty of Dentistry, Trisakti University, Indonesia \\ ${ }^{2}$ Department of Microbiology, Faculty of Dentistry, Trisakti University, Indonesia
}

Received date: August 21, 2019. Accepted date: November 16, 2019. Published date: February 20, 2020.

\section{KEYWORDS}

Myrmecodia pendans; Streptococcus sanguinis; Treponema denticola; biofilm

\begin{abstract}
Introduction: Ant-nest plant (Myrmecodia pendans) contains triterpenoid, flavonoid, saponin and tannin that acts as antibacterial substance. Objectives: This study's aim was to analyze the effect of Myrmecodia pendans extract effect towards biofilm of Streptococcus sanguinis and Treponema denticola. Methods: Ant-nest plant was extracted using maceration technique. The obtained extract was diluted into five different concentrations using phosphate buffer saline (PBS). S. sanguinis and T. denticola ATCC 35405 were cultured in Brain Heart Infusion (BHI) broth, $48 \mathrm{~h}, 37^{\circ} \mathrm{C}$, anaerobic atmosphere and distributed into four 96 well-plate for $24 \mathrm{~h}$ to form biofilm. Subsequently, the extract was distributed into the well that contained the mono-species and multispecies biofilm and then incubated for $1 \mathrm{~h}, 3 \mathrm{~h}, 6 \mathrm{~h}$ and $24 \mathrm{~h}$. Chlorhexidine $(0.2 \%)$ was used as positive control and BHI broth was used as negative control. The biofilm was stained using crystal-violet and measured by microplate reader with a wavelength of $490 \mathrm{~nm}$. Data were statistically analyze using one-way ANOVA test and Post Hoc LSD test which $p<0,05$ was set as significant difference. Result: The most effective concentrations to reduce monospecies biofilm were $100 \%$ in $1 \mathrm{~h}$ incubation period for $S$. sanguinis $(\mathrm{OD}=1,403 \pm 0,019)$ and $24 \mathrm{~h}$ for $T$. denticola $(\mathrm{OD}=1,012 \pm 0,037)$ and multispecies biofilm $(\mathrm{OD}=0,984 \pm 0,001)$ compared to negative control. Statistical analysis showed that ant-nest plant extract significantly reduced $S$. sanguinis, $T$. denticola and multispecies biofilm mass compared to negative control $(\mathrm{p}<0,05)$. Conclusion: The ant-nest plant extract has inhibitory effects against $S$. sanguinis and $T$. denticola biofilm and it may be used as alternative for dental therapy. Future studies are needed to evaluate the potential of ant-nest plant extract in multispecies composed of other oral bacteria.
\end{abstract}




\section{INTRODUCTION}

Two common dental and oral health diseases are dental caries - also known as cavities - and periodontal disease. There are two main types of periodontal tissue inflammation gingivitis and periodontitis. ${ }^{1}$ The inducer of these inflammation are bacterial species in sub-gingival plaque. Gingivitis, which is an inflammation on gingiva can be prevented by plaque removal, such as by brushing your teeth regularly. Periodontitis is marked by periodontal tissue damage and the loss of connective tissue attachments, alveolar bone loss, and pathological pockets surrounding the tooth. ${ }^{2}$ One of the causes of this periodontal infection is biofilm. ${ }^{3}$ Biofilm is a thin layer of microorganisms adhering to a solid surface and covered by a matrix of organic substances (polysaccharides, extracellular DNA (eDNA), and proteins). ${ }^{4}$ The production of this extracellular matrix protects the bacteria from the surrounding area, including from chemotherapeutic agents. ${ }^{5}$

Streptococcus sanguinis is an anaerobic, facultative, Gram-positive bacterium found in the oral cavity that is involved in biofilm development. ${ }^{6} S$. sanguinis has a role in development of periodontal disease. ${ }^{7}$ Treponema denticola is a common spirochete found in sub-gingival plaque and has a role in the development of chronic periodontitis, acute necrotizing ulcerative gingivitis (ANUG), infected root canal, and acute abscess. ${ }^{8}$ These bacteria have some common virulence factors such as major sheath proteins (MSPs), lipoproteins, lipopolysaccharides (LPSs), dentilisin, peptidoglycan, cystalysin, peptidases, and phosphatases, which can cause inflammation and induce the host cell to produce chemical mediators, all of which involved in damaging periodontal connective tissues. ${ }^{9}$

About $70-80 \%$ of the world's population uses herbal and natural ingredients for health care, prophylaxis, and oral lesion treatment. The most populated countries, such as China and India, have been using natural remedies for over 2000 years to cure oral diseases, including periodontal disease. ${ }^{10}$ For example, pineapple stem extracts contain high levels of bromelain, an enzyme which acts as an antibacterial agent against Enterococcus faecalis. ${ }^{11}$ Strawberry extracts have been proven to delay biofilm formation of E. faecalis and Porphyromonas gingivalis in vitro. ${ }^{12}$ Pomegranates contain significant amounts of ellagic acid, which displays antibacterial activity against Candida albicans..$^{13}$ Myrmecodia pendans (ant nest plant) is a plant from Papua in eastern Indonesia, where it is well known as herbal remedy. $M$. pendans is commonly used in western Papua as a traditional medicine for many diseases. ${ }^{14}$ Previous studies showed that ant nest plant extracts display antimicrobial activity towards Streptococcus mutans and E. faecalis. ${ }^{14,15}$ However, M. pendans extract has not been known to decrease biofilm formation of periodontal pathogens such as $S$. sanguinis and $T$. denticola.

\section{MATERIALS AND METHODS}

This study is an in vitro experimental laboratory with post-test only control design. This study was conducted in Microbiology Centre of Research and Education (MiCORE) laboratory, Faculty of Dentistry, Trisakti University, Jakarta, Indonesia. The plant used in this study was $M$. pendans which obtained from local society in Papua island which is located in eastern Indonesia.

\section{Myrmecodia pendans Extraction}

Dried $M$. pendans plant was washed in running water until clean and rinsed with aquadest to remove sticky soil on the plant's surface. The dried sample was blended into a powder and sieved. Extracts were obtained from as much as $50 \mathrm{~g}$ of powder using a maceration technique, wherein the sample was soaked in $500 \mathrm{~mL}$ of $70 \%$ ethanol for 5 days. The sample was then left for $24 \mathrm{~h}$ and filtered with filter paper. Filtrate was evaporated using a rotary evaporator at $40^{\circ} \mathrm{C}$. The $100 \%(\mathrm{v} / \mathrm{v})$ extract was diluted in brain heart infusion (BHI) broth (Thermo Scientific, Waltham, MA, USA) to $50 \%, 25 \%, 12.5 \%$ and $6.25 \%(\mathrm{v} / \mathrm{v})$.

\section{Bacterial culture and Biofilm Assay test}

Brain heart infusion (BHI) broth was used to grow $S$. sanguinis and T. denticola ATCC 35405 and the bacteria were incubated at $37^{\circ} \mathrm{C}$ in an anaerobic atmosphere for 24h using GasPak jar system (Becton Dickinson, Franklin Lakes, NJ, USA). The bacterium culture in broth medium was measured at $600 \mathrm{~nm}$ and diluted to obtain a suspension of McFarland standard 0.5 (equivalent to $1,5 \times 10^{8} \mathrm{CFU} / \mathrm{mL}$ ). After homogenizing, the bacterium suspension was distributed into a 96-well plate, and incubated at $37^{\circ} \mathrm{C}$ for $24 \mathrm{~h}$ in an anaerobic atmosphere to formed biofilm. The supernatant was removed and the biofilm attached on the bottom of well plate was rinsed with phosphate buffer saline (PBS). 200 uL $M$. pendans extracts with different concentrations $(100 \%, 50 \%, 25 \%, 12.5 \%$ and $6.25 \%)$ were distributed into the well plate. Chlorhexidine $(1.2 \%)$ was used for the positive control and biofilm wells without herbal tested was used for the negative control. Inhibitory effects were observed after incubation at $37^{\circ} \mathrm{C}$ for $1 \mathrm{~h}, 3 \mathrm{~h}$ $6 \mathrm{~h}$, and $24 \mathrm{~h}$ in an anaerobic atmosphere. Crystal violet dye $(0.5 \% \mathrm{w} / \mathrm{v})$ was distributed into the well plate and incubated for $15 \mathrm{~min}$. The extraction of the remaining crystal violet dye in the well plate was measured after the addition of $200 \mu \mathrm{L} 90 \%$ ethanol and the absorbance was measured using a microplate reader at $595 \mathrm{~nm}$. 


\section{Statistical Analysis}

The data was statistically analyzed using a one-way ANOVA test and a Post Hoc LSD test in which p<0.05 was set as the significant difference. Statistical calculations were performed with SPSS Statistics for Windows software (IBM, Armonk, USA).

\section{RESULTS}

Results showed that there were significant reductions of mono-species S. sanguinis biofilm mass (Optical density/OD \pm mean) after treatment with ant nest plant extract for all incubation periods $(p<0.05)$. The most effective concentration to reduce $S$. sanguinis biofilm was $100 \%$ with a 24 -hour incubation time-period $(\mathrm{OD}=$ $1.403 \pm 0.019)$ compared to the negative control (OD = $3.354 \pm 0.011$ ) with $58.2 \%$ of biofilm reduction (Fig 1).

There were significant reductions of mono-species biofilm of $T$. denticola biofilm mass after treatment with ant nest plant extract for all incubation periods $(p<0.05)$. The most effective concentration to reduce $T$. denticola biofilm was $100 \%$ with a 24 hour incubation period (OD $=1.012 \pm 0.037)$ compared to negative control $(\mathrm{OD}=$ $3.327 \pm 0.157$ ) with $69.6 \%$ of biofilm reduction (Fig 2).

Results also showed that there were significant reductions of mixed-species biofilm mass after treatment with ant nest plant extract for all incubation periods ( $p<$ 0.05 ). The most effective concentration was $100 \%$ with 24 hour incubation period $(\mathrm{OD}=0.984 \pm 0.001)$ compared to the negative control $(\mathrm{OD}=3.383 \pm 0.004)$ with $70.9 \%$ of biofilm reduction (Fig. 3). Furthermore, there were no significant difference of monospecies biofilm of $S$. sanguinis, $T$. denticola and mixed biofilm mass reduction after treatment with ant nest plant extract $(100 \%)$ compared to positive control $(p>0.05)$. Thus, this plant extract has the ability to inhibit biofilm formation as effective as chlorhexidine in this study.

\section{DISCUSSION}

In this study, ant nest plant (M. pendans) extract was tested for its effectiveness against $S$. sanguinis and $T$. denticola biofilm formation for both mono- and mixedspecies biofilm. Study report the analysis of gene expression profiles in $T$. denticola triggered by the contact with other relevant oral bacterial species including two representatives each for the red $(P$. gingivalis and $T$. forsythia), orange ( $F$. nucleatum and $P$. intermedia), and yellow ( $S$. gordonii and $S$. sanguinis) complexes. The extent of observed transcriptional responses in $T$. denticola appears to reflect previously established disease-related associations, interspecies interactions and synergistic relationships. ${ }^{16}$ The results

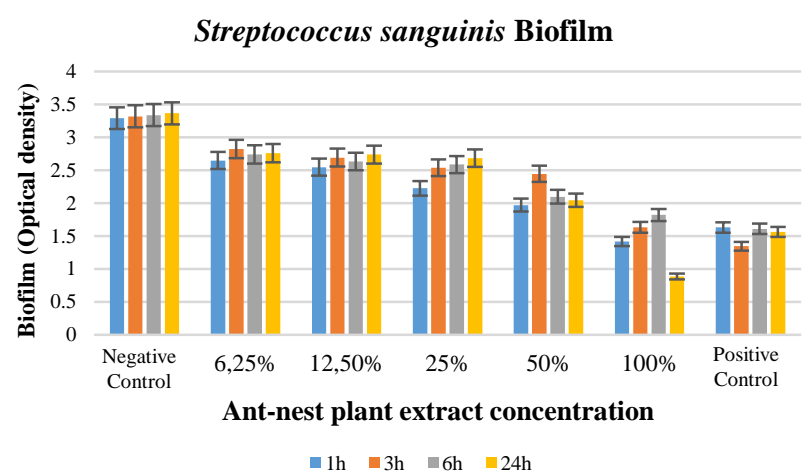

Figure 1. Streptococcus sanguinis biofilm reduction (optical density) after treatment with ant nest plant extract with $100 \%, 50 \%, 25 \%, 12,5 \%$, $6,25 \%$ concentration in different incubation time $(1 \mathrm{~h}, 3 \mathrm{~h}, 6 \mathrm{~h}, 24 \mathrm{~h})$. Chlorhexidine $(0,2 \%)$ was used as positive control and BHI broth was used as negative control.

Treponema denticola Biofilm

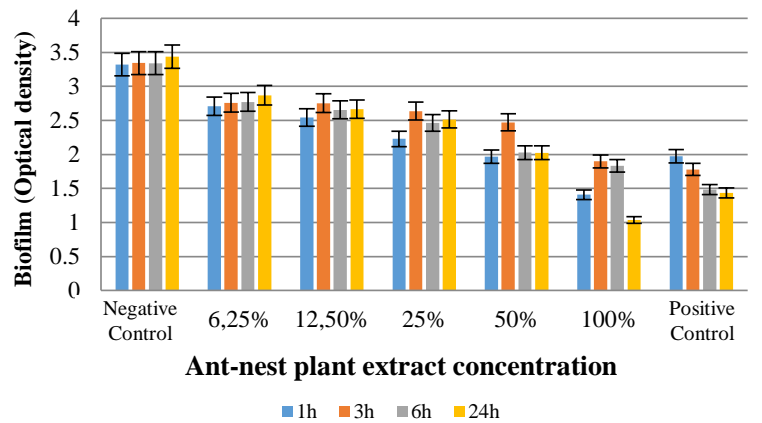

Figure 2. Treponema denticola biofilm reduction (optical density) after treatment with ant nest plant extract with $100 \%, 50 \%, 25 \%, 12,5 \%$, $6,25 \%$ concentration in different incubation time (1h, 3h, 6h, 24h). Chlorhexidine $(0,2 \%)$ was used as positive control and $\mathrm{BHI}$ broth was used as negative control.

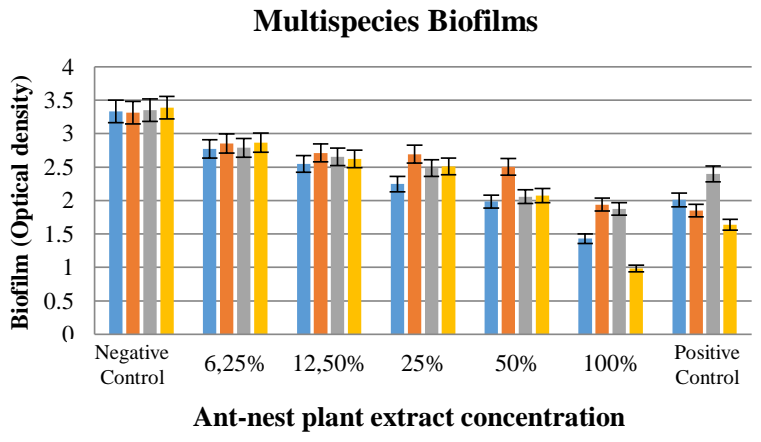

$\square 1 \mathrm{~h} \quad \square 3 \mathrm{~h} \quad \square 6 \mathrm{~h} \quad \approx 24 \mathrm{~h}$

Figure 3. Multispecies biofilm reduction (optical density) after treatment with ant nest plant extract with $100 \%, 50 \%, 25 \%, 12,5 \%$, $6,25 \%$ concentration in different incubation time $(1 \mathrm{~h}, 3 \mathrm{~h}, 6 \mathrm{~h}, 24 \mathrm{~h})$. Chlorhexidine $(0,2 \%)$ was used as positive control and $\mathrm{BHI}$ broth was used as negative control.

showed an inhibitory effect for all incubation periods against the periodontal pathogens as mono and mixed species, with the most effective concentration being $100 \%$. The lowest optical density in this study is on mixed species biofilm, since both strains have a 
synergistic relationship, this ant nest plant extract may be have the ability to interfere the synergistic relationship in both strain and inhibit the biofilm mass.

A maceration technique was used to acquire the ant nest plant extract. It is an active substance retrieval performed by soaking a simplified powder in a solvent for some days at room temperature and protected from the light. The solvent will penetrate into the cell wall of the simplified powder and infiltrate the cell cavity which contains the active substances. These active substances will be dissolved due to the different concentrations of solvent inside and outside the cell, causing the concentrated solvent to be pushed out. This process was repeated until a balanced concentration of the solvent was achieved inside and outside the cell. The advantage of the maceration technique is that it uses simple tools and it does not destroy heat-sensitive active substances. ${ }^{17}$

Previous studies that were done by Roslizawaty et al., in 2013 showed that $M$. pendans decreased $C$. albicans growth. From the saturation level in test tubes of fungus and $M$. pendans, it was proven that there was an increasing inhibitory effect of ant nest extract on $C$. albicans at higher concentrations. ${ }^{18} \mathrm{M}$. pendans belongs to the Rubiaceae family. It contains many active phytochemicals, mostly phenolic compound groups such as flavonoids, tannins, saponins, phenolic acids, alkaloids, triterpenoids, and glycosides. ${ }^{19} M$. pendans displays two antibacterial mechanisms, which are cytotoxicity and apoptosis. Cytotoxicity is a characteristic that can slow and prevent microbial cell growth, which has potential to harm healthy host cells..$^{14,20}$

Biofilm is one of the major factors that contribute to periodontal diseases. It is resistant to some antibiotics and chemical agents because of its extracellular matrix, which prevents the penetration of therapeutic agents. ${ }^{21}$ That is why in this study, higher concentrations of ant nest plant were required to eradicate more biofilm. The eradication of bacteria was mostly based on the inhibition of cell wall synthesis, protein synthesis, enzyme activity, or nucleic acid metabolism. ${ }^{22}$

Terpenoids, which are some of the potential active substances in the ant nest plant, are able to damage the planktonic cells from biofilms and also disturb the membrane integrity of bacterial cells. Previous studies also suggested that flavonoids were another substance group that would decrease biofilm formation. ${ }^{12,23,24}$ Flavonoids, as the most widely distributed phenolic compound in the nature, have been reported to exhibit three different mechanisms of antimicrobial activity. They inhibit microbial nucleic acid synthesis, damage the microbial cytoplasmic membrane which leads to cell perforation, and sabotage the metabolic processes in many microorganisms. ${ }^{25}$ Most plant phenolic compounds also have antibiofilm effects because they interfere with quorum sensing, which can affect the growth of many bacteria. ${ }^{26}$

\section{CONCLUSION}

Based on this study, it can be concluded that Myrmecodia pendans extract has an antibiofilm effect on $S$. sanguinis and $T$. denticola biofilm as mono and multispecies. Ant nest plant (M. pendans) extract may be used as an alternative antibacterial agent to inhibit bacterial activities in the oral cavity. Future studies are needed to evaluate the potential of ant nest plant extract.

\section{CONFLICT OF INTEREST}

The authors declare that they have no conflicts of interest.

\section{REFERENCES}

1. Shaw L, Harjunmaa U, Doyle R,Mulewa S, Charlie $\mathrm{D}$, Maleta $\mathrm{K}$, et al. Distinguishing the signals of gingivitis and periodontitis in supragingival plaque: a cross-sectional cohort study in Malawi. Appl Environ Microbiol.2016; 82 6057-6067.

2. Taylor JJ. Protein biomarkers of periodontitis in saliva. ISRN Inflamm. 2014; 2014:593151.

3. Eberhard J, Grote K, Luchtefeld M,HeuerW, Schuett $\mathrm{H}$, Divchev D, et al. Experimental gingivitis induces systemic inflammatory markers in young healthy individuals: A single-subject interventional study. PLOS ONE.2013;8:e55265.

4. Wei Q, Ma LZ. Biofilm matrix and its regulation in Pseudomonas aeruginosa. Int $\mathrm{J}$ Mol Sci. 2013;14:20983-21005.

5. Seneviratne CJ, Zhang CF, Samaranayake LP. Dental plaque biofilm in oral health and disease. Chin J Dent Res Off J Sci Sect Chin Stomatol Assoc CSA. 2011;14:87-94.

6. Liu J, Stone VN, Ge X, Tang M, Elrami F, Xu P. TetR family regulator brpT modulates biofilm formation in Streptococcus sanguinis. PLOS ONE. 2017;12:e0169301.

7. Xu P, Alves JM, Kitten T, Brown A, Chen Z, Ozaki LS, et al. Genome of the opportunistic pathogen Streptococcus sanguinis. J Bacteriol. 2007;189: 3166-75.

8. Dashper SG, Seers CA, Tan KH, Reynolds EC. Virulence factors of the oral spirochete Treponema denticola. J Dent Res. 2011;90:691-703.

9. Chukkapalli SS, Rivera MF, Velsko IM, Lee JY, Chen H, Zheng D, et al. Invasion of oral and aortic tissues by oral spirochete Treponema denticola in ApoE-/- mice causally links periodontal disease and 
atherosclerosis. Infect Immun. 2014;82:1959-1967.

10. Kala BS, Gunjan C, Disha N, Shobha P. Treatment of periodontal disease - A herbal approach. Int J Pharm Sci Rev Res.2015;33(2):126-36.

11. Liliany D, Widyarman AS, Erfan E, Sudiono J, Djamil MS. Enzymatic activity of bromelain isolated pineapple (Ananas comosus) hump and Its antibacterial effect on Enterococcus faecalis. Sci Dent J. 2018;2(2):39-50.

12. Widyarman AS, Widjaja SB, Idrus E. Strawberry extract's effects on Enterococcus faecalis and Porphyromonas gingivalis biofilms in vitro. Sci Dent J. 2017;1(1):1-5.

13. Hernawati S, Rantam FA, Sudiana IK, Rahayu RP. Efek ekstrak buah delima (Punica Granatum L) terhadap ekspresi wild p53 pada sel ganas rongga mulut mencit strain Swiss Webster. Dent J Maj Kedokt Gigi. 2013;46:148-51.

14. Gartika M, Pramesti HT, Kurnia D, Satari MH. A terpenoid isolated from sarang semut (Myrmecodia pendans) bulb and its potential for the inhibition and eradication of Streptococcus mutans biofilm. BMC Complement Altern Med. 2018;18:151.

15. Kuswandani F, Satari MH, Maskoen AM. Antimicrobial Effifficacy of Myrmecodia pendens Extract and Fraction Combination against Enterococcus faecalis ATCC 29212. J. Dent Indonesia 2019; 26(3); 119-25

16. Sarkar J, McHardy IH, Simanian EJ, Shi W, Lux R. Transcriptional responses of Treponema denticola to other oral bacterial species. PLoS One. 2014; 9:e88361.

17. Azmir J, Zaidul ISM, Rahman MM, Sharif KM, Mohamed A, Sahena F, et al. Techniques for extraction of bioactive compounds from plant materials: A review. J Food Eng. 2013;117: 426-36.
18. Efendi YN, Hertiani T. Antimicrobial potency of ant-plant extract (Myrmecodia tuberosa jack.) against Candida albicans, Escherichia coli, and Staphylococcus aureus. Maj Obat Tradis Tradit Med J. 2015;18:53-8.

19. Engida AM, Kasim NS, Tsigie YA, Ismadji S, Lien $\mathrm{HH}$, Yi-Hsu J. Extraction, identification and quantitative HPLC analysis of flavonoids from sarang semut (Myrmecodia pendan). Ind Crops Prod. 2013;41:392-6.

20. Kurnia D, Apriyanti E, Soraya C, Satari MH. Antibacterial Flavonoids Against Oral Bacteria of Enterococcus Faecalis ATCC 29212 from Sarang Semut (Myrmecodia pendans) and Its Inhibitor Activity Against Enzyme MurA.2019;16(3):290-296

21. Chandki R, Banthia P, Banthia R. Biofilms: A microbial home. J Indian Soc Periodontol. 2011; 15:111-4.

22. Nazzaro F, Fratianni F, De Martino L, Coppola R, De Feo V. Effect of essential oils on pathogenic bacteria. Pharmaceuticals. 2013; 6:1451-74.

23. Widyarman AS, Sumadi S, Agustin TP. Antibiofilm Effect of Clitoria ternatea Flower Juice on Porphyromonas gingivalis in vitro. J Indones Dent Assoc. 2018; 1(1): 7-12.

24. Radita DC, Widyarman AS. Mahkota Dewa (God's Crown) Fruit Extract Inhibits the Formation of Periodontal Pathogen Biofilms in vitro. $\mathrm{J}$ Indones Dent Assoc . 2019; 2(2): 57-62.

25. Slobodníková L, Fialová S, Rendeková K, Kováč J, Mučaji P. Antibiofilm activity of plant polyphenols. Mol Basel Switz. 2016;21(12):E1717.

26. Silva LN, Zimmer KR, Macedo AJ, Trentin DS. Plant natural products targeting bacterial virulence factors. Chem Rev. 2016; 116:9162-236. 